\title{
承久度鷹尾神社本殿 \\ THE HONDEN OF TAKAO SHRINE BUILT IN 1219
}

\author{
山口佳巳* \\ Yoshimi YAMAGUCHI
}

\begin{abstract}
The honden of Takao Shrine was reconstructed in 1213 and the sengu took place in 1219. Some documents including the plan and the order for woods have been remained about this reconstruction. The purpose of this study is to clarify the style and the origin of the honden in 1219 from these documents.

This analysis revealed that the honden had some humble features. We consider that it became impossible to maintain the former style by reason of economy. Furthermore the honden had something in common with Kora Shrine's honden. Therefore we conclude that Takao Shrine was derived from Kora Shrine.
\end{abstract}

Keywords: Nagare-style, Kora Shrine, Betsugu, Order for woods, Plan 流造, 高良大社, 別宮, 用材注文, 指図

\section{1. 緒言}

鷹尾神社は、福岡県柳川市大和町鷹ノ尾に鎮座し、応神天皇・仲 哀天皇・神功皇后を祀る。筑後一宮高良大社の別宮であるとともに、 瀬高下荘の鎮守でもあった。

当社は、建暦三年 (1213) に社殿が焼失し、承久元年 (1219) に遷宮 が行われた。その承久度再建に際して提出された本殿の用材注文と 遷宮時の指図が伝えられており、それらにより承久度本殿の構造形 式を具体的に復元することが可能である。これまでに佐藤正彦氏 ${ }^{1}$ と永井規男氏 ${ }^{2}$ による二つの復元案があるが、いずれも史料を十分 に活かした論考とは言い難く賛同できるものではない。そこで本稿 では、史料を再検証した上で改めて復元考察し、承久度本殿の建築 史上における特質について新たな見解を示したい。

承久度本殿は三間社流造であったが、同形式の現存遺構は建保七 年 (1219)の神谷神社本殿が最古例であり、それを遡るものはない。 また、谷重雄氏の論考 ${ }^{3}$ において、嘉元造替の上賀茂神社本殿は破 風板を身舎と庇で別材としていたことが明らかにされており、鎌倉 時代は流造本殿の細部形式の変遷過程にあった時期でもある。した がって、承久度本殿は類例の乏しい鎌倉時代前期における流造本殿 の一形式を示寸貴重な例であるとともに、流造本殿の発展過程につ いて新たな知見を提供する重要な例と言える。

なお、鷹尾神社の文献資料に関しては、先行研究において熊本中 世史研究会編になる活字本『筑後鷹尾文書』 ${ }^{4)}$ に所収された文書が 用いられてきたが、一部に誤読が認められる。本稿では、重要とな る文書については、その後刊行された柳川古文書館編になる写真本
『筑後鷹尾文書』 ${ }^{55}$ にいて確認し、明らかな誤読は訂正して引用 することにした。

\section{2. 当社の概要}

\section{(1) 沿革}

鷹尾神社は、社伝によると貞観十一年 (869) の勅建という注1)。当 社に関する資料上の初見は、保元四年 (1159)の「高良別宮供下支配 注文」注2) であり、「高良別宮」として現れる。この頃の本殿につい ては断片的な記録に頼るほかないが、承元元年 (1207)の「祭礼日 記」注3)に「口於御宝殿上之差萱修理者、雖元宮移可差也」とあり、

「御宝殿」(本殿)の屋根を「差萱」すなわち茅莫の屋根の腐朽部に 茅を補充して修理する旨が記されている。また、建暦二年 (1212)の 「鷹尾社祭礼神官装束等覚拜御財物日記」洋) には、「注進、建暦二 年〔壬申〕瀬高下御庄別宮御前修理次第日記事、合檜皮百五十井、 莫手八高佐後舟請」（〔 〔 内は割註を示す。以下同じ。）とあり、 「檜皮百五十井」が注進されていることから、当時の本殿は檜皮莫 であったと考えられる。同年十一月には遷宮が行われた洋5) という。

その翌年、建暦三年の「鷹尾社焼失日記 (断簡)」注(6)に、

建暦三年〔癸西〕四月廿五日〔丙申〕夜、大宮司紀真大夫元真 被夜打〔仁〕打、依類火宮稗 $\square$ 焼失了、紀真太夫内方被打害焼 失火也、但竹尾御目代 $\square$ 汰候時、御祭同年四月十七日戊子、同 廿五日如此有質

とあり、大宮司紀真大夫元真が夜討ちされた際、類火により宮が焼

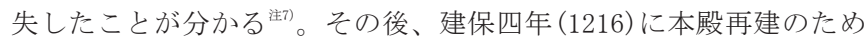


に用材の注文が提出され ${ }^{\text {i:8) }}$ 、承久元年に遷宮が行われた ${ }^{\text {湆 }}$ という。

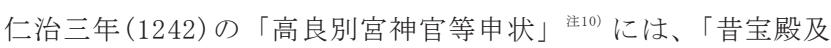
大破、礎石徒変苔下、悲哉、今仮屋忽令朽損夢不全」とあり、宝殿 は昔に大破し、その礎石が苔の下に埋もれてしまっており、今では 仮屋であるという。この時、「御宝殿已下宮社神宮寺科御神興等」 を先例に任せて造営されるように申し進めている。後の記録によれ ば、造営料の不足や未納があったが秘計を廻らして造営の功を修め たという涐11)。

そして、弘長三年 (1263)の「鷹尾社神官等言上状案(前欠)」 に「其後又依経年序、柱 $\square \square \square$ 全令朽損莫板、御正体為雨露」とあ り、莫板が朽損していることが分かる。それを受けて、本殿の上莫 用途が注文されている ${ }^{\text {㳯 } 13)}$ 。その中に「梖榑三千五百枝〔長七尺、 広四寸五分、厚一寸」」とあり、屋根は槙博を用いた板莫であった ものと考えられる。修理後、文永二年 (1265) に遷宮が行われている 注14)。さらに、弘安八年 (1285) に修理用途が注文され注15) 、正応五年 $(1$ 292) に遷宮が行われている㳯16)。このように、承久度に再建されて から約二十年間隔で、屋根の莫替が行われていることが分かる。

年紀未詳の「鷹尾社造営願案(後欠)」洋17)によれば、文亀二年 $(15$ 02) 九月に「神殿及破壊候二付而、古例之通造営之」とあり、神殿 すなわち本殿が破壞したので古例の通りに造営したという。また、 その百年余り後の「立斎様御代」寸なわち当地の領主立花宗茂の代 に再び本殿が破壊した際には、本殿のみならず楼門ほかも建立した ことが知られる ${ }^{* 18)}$ 。それから年々破損し莫板が朽ち雨漏するので、

「先年奉願候処二、茅を以上莫被仰付」すなわち先年の願が認めら れ、屋根は茅で蕞くように仰せ下されたという售19)。江戸時代を通 じて立花氏の庇護を受け、現在の本殿は柳川藩記録により天保四年 (1833)の再建とされている注20)。

\section{(2) 現在の本殿}

現在の本殿は、桁行三間・梁間三間に一間の向拝を付す。屋根は、 入母屋造で銅板莫とし千木・堅魚木を載せる。周囲には切目縁を廻 らせ、刎高欄を設ける。また、廻縁の途中には板壁のない脇障子を 立てる。

桁行三間・梁間二間を内陣とし、その前面一間通りを外陣とする。 内陣後方には柱を立てて間仕切り、内々陣とする。内陣正面すなわ ち内外陣境は御䇥を垂れるのみとし、内陣の側面・背面は板壁とす る。外陣正面は内開きに部を吊り、両側面は片引戸を建てる。また、 内々陣正面は三柱間ともに板扉を開く。

基壇上に土台を廻らせ、内陣回りは円柱、外陣正面は角柱を立て る。縁長押・内法長押・頭貫 (先端は木鼻) で柱を固める。内外陣境 において、内陣側の床を長押一本分高める。そのため廻縁にも段が 付く。組物は拳鼻付の平三斗とし実时木で桁を受け、中備は本蟇股 とする。二軒繁垂木である。内外陣ともに内部は出組の一種である 亜麻組とし、中備には本蟇股を配す。また、畳敷で竿縁天井を張る。

\section{3. 先行研究と問題点}

承久度本殿を復元的に研究した論考として、佐藤氏の「鷹尾神社 本殿について一承久元年再建時の指図より一」と永井氏の「鷹尾神 社承久再建本殿の建築構成について」が挙げられる。両者が復元史 料として用いたのは、活字本『筑後鷹尾文書』に所収された建保四 年の「御宝殿造営用材注文」注21) (以下、「用材注文」とする) と承
久元年の「鷹尾社遷宮宝殿指図扭用途直法等注文」注22)（以下、「宝 殿指図」とする)の二通である。

\section{(1) 佐藤案}

佐藤氏は、その論考において復元図は提示していないが、復元考 察を行っている。まず規模形式については、「宝殿指図」にある「三 間一面広庇」という記述と指図により、桁行三間・梁間二間の身舎 前面に一間の庇を付けた流造で、庇回りにのみ縁を廻らすものとす る。また、同文書の記述により、正面三間は格子(部)、庇の向かっ て左側面は「妻戸」（引違戸もしくは片引戸と推測）とし、その他の 柱間は寸べて蠣灰塗(漆喰塗)とする。そして、「用材注文」の「起 橋木四支〔長九尺、同下桁〕」という記述により、正面中央間の縁 の前に長さ九尺の階段が設けられていたらしいとする。さらに、屋 根については、「宝殿指図」の平面指図内の「裏板三間皆打遂上柏 板以鎧莫ス」及び本文記事中の「瓦五千余枚」という記述から、瓦 莫であったことは確かであろうと述べている。

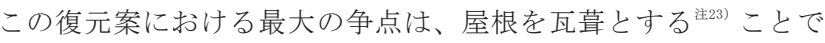
あろう。鎌倉時代前期の神社本殿が瓦草であったとするのは、いく ら地方であったとしても早計と言わざるをえない。この点に関して は永井氏も異論を唱えているが、後述するように本稿の見解とは異 なるものである。重大な問題であるので、改めて検証しておく。

まず、佐藤氏が瓦莫の根拠として挙げた「宝殿指図」の記述を見 ていきたい。「裏板三間皆打遂上柏板以鎧莫ス」は、裏板三間は皆 打ち遂げ、上の栢板で以て鎧莫すと読める。佐藤氏は、この「鎧莫」 を瓦蕞の証拠の一つとしているようであるが、鎧のように段を付け て柏板を草くもの、寸なわち板草あるいは栃草であったことは想像 されるものの、特に瓦莫である必要はない。また、「瓦五千余枚」 の「瓦」という字を写真本『筑後鷹尾文書』にて確認したところ、 「凡」(「瓦」とは似るが上の一画がなく、凡の異体字である) と記 されており、翻刻時の誤読であることが分かった。これを含む一文 を改めて引用すると、

母屋二間平殿上柏板長三尺、面四五六寸、若檐板七八寸、凡五 千余枚、直米八石余下取、鎧莫〔スル〕也 となり、「栢板」、檐板」という板材に続いて唐突に「瓦五千余枚」 とするよりも、それらの板材が「凡(およそ)五千余枚」とする方が、 文脈上においても適当であろう。なお、付け加えるならば、瓦五千 余枚に対して直米八石余では瓦一枚の值段が僅か米一合六勺程度と なり、あまりにも安すぎる。したがって、佐藤氏が示した根拠はい ずれも瓦莫を証明するものとは言えず、その復元案についても信を 置きがたい。

\section{(2) 永井案}

一方、永井氏は、佐藤氏の復元案をやや批判的に捉え、同一の史 料を用いてより具体的に復元考察を行い、復元図 (平面図・正面立 面図・側面立面図)を提示している。永井氏の復元案は、桁行三間 (柱 間 6 尺 2 寸) ・ 梁間二間 (柱間 5 尺5寸)の身舎の前面に一間 (柱間 5 尺 5 寸)通りの庇を付けた平面とする。すなわち、三間一面の流造、平 入である。庇を取り囲むように榑縁を廻らせる。脇障子は立てず、 いずれの隅も刎高欄とする。正面中央には、四級の木階を設ける。 身舎と庇で段差を付けた亀腹上に礎石を据え柱を立てる。身舎は円 柱、庇は角柱とし、総柱平面とする。身舎柱は腰長押・内法長押、 庇柱は縁長押・内法長押で固め、身舎・庇境においては、各長押を 
背違いにして身舎を一段高くする。組物は舟肘木とし、妻梁も舟肘 木で受ける。また、妻梁上には双首(合掌)を組み、斗で棟木を受け る。本文記述によれば、垂木は身舎・庇ともに大疎垂木とする。破 風板は身舎・庇境よりも少し庇側寄りで継ぐ。屋根は柏板を「鎧莫」 とする。柱間装置については、正面三間は格子 (部)が嵌り、庇の向 かって左側面は妻戸(開戸)とする。それ以外はすべて板壁であって、

蠣灰塗としていたとする。

この復元案における大きな問題として三点が挙げられる。まず、 双首についてであるが、永井氏は「用材注文」に「指十二」とある のは「指寸二」であるとし、「指寸」はサスと読み、二組の双首と 解䣋し、妻壁にのみ配している。しかし、建物内部において双首笔 のみの双首とするのは類例が少なくないが、妻壁においては一般的 に双首束を加えて豕双首とす心゙きであって、扠首竿のみの類例はな い。さらに、梁間断面図が提示されていないため判然としないが、 扠首が妻壁にしかないとすると、棟木は妻壁と扠首のみで支えられ ることとなり、内部では棟木を支える部材がなく、ただ梁を架ける のみとなってしまう。そもそも、「寸」と「十」は書き誤る可能性 は少ないもので、染意的な解釈とも言える。また、「指」だけでサ スと読める。

続いて舟肘木についてであるが、永井氏は柱頂には肘木だけが置 かれた舟肘木組であったとしている。但し、「用材注文」には「臂 木十六」と十六支の肘木が注文されており、それらの肘木をすべて 舟肘木として柱頂に使うならば、妻梁下のみならず身舎内部に立つ 柱の頂部にも舟肘木を配して梁を受けることになり、不適当な納ま りである。また、身舎側柱と庇柱のみに舟肘木を配すとすれば、注 文された肘木が二支余ることになり、注文との相違が生じる。いず れにしても、肘木の使い方に問題があると言わざるをえない。

最後に破風板についてである。破風板を身舎と庇で分けて注文す ることは間々見られることであるが、嘉元造替の上賀茂神社本殿と 同様に継ぎ、流造の古い形式とするのは後述するように安直である。 以上のように、永井氏の復元考察も不十分である。

\section{4. 復元史料}

本稿における主な復元史料は、先行研究と同様に建保四年「用材 注文」と承久元年「宝殿指図」の二通である。以下に、その二通を 掲げておく。なお、活字本の誤植等は写真本により訂正しておいた。

\section{「用材注文」}

$\square$ 尾宮御宝殿造営料別宮御宝殿寸法事

$\square$ (三か) 間一面〔間六尺二寸〕

柱十六本〔長九尺六寸三分、 九寸

桁三枝〔長二丈六尺六寸、四五寸〕

棟一支、長桁同〔四五寸〕

長押廿四支内〔長二丈注24) 十二支、一丈二尺六支、七尺六支〕

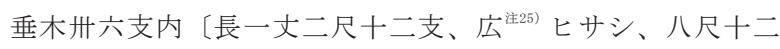
支、一丈三尺十二支、母屋後 ${ }^{(i 26)}$ ]

梁四枝〔長一丈三尺、五六寸〕

指十二

博風六枚、開板二枚〔長同桁〕

斗二、臂木十六

大床下梁四支〔五六寸、長一丈三尺〕
縁柱十本〔長三尺、口六寸〕

勊橋木四支〔長九尺、同下桁〕

木舞廿四支

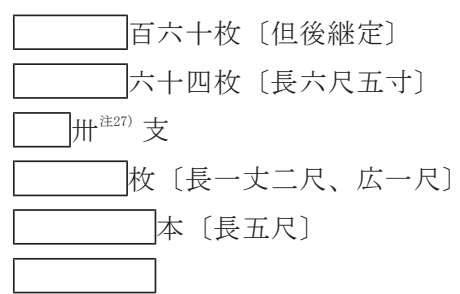

縁角木二支〔長七尺、五六寸〕

右、注文大略如件、

建保四年〔丙子〕九月

この文書は、冒頭に「口尾宮御宝殿造営料別宮御宝殿寸法事」と あり、建築部材名称・員数・寸法を明記した用材注文であることが 分かる。詳しくは後述するが、「宝殿指図」に示された本殿の規模 と、この「用材注文」により復元される規模が一致するため、同一 の建物を示しているとしてよい。但し、後半に欠落箇所があり、す べての用材を知ることはできない。

\section{「宝殿指図」}

(前欠)

御宝殿三間一面広庇

(平面指図)

如此名 >一間宛塗蠣圧名別二斗宛入

右、御宝殿間宛如此、柱長八尺五寸、口七寸五分、梁一丈一尺、 間五尺五寸、正面広庇五尺五寸、高七尺五寸、飛檐三尺五寸、 檐雨打四尺二寸、妻差出雨打四尺五寸、裏板、母屋庇皆打遂也、 母屋二間平殿上柏板長三尺、面四五六寸、若檐板七八寸、凡 ${ }^{i 228}$ 五千余枚、直米八石余下取、鎧莫〔スル〕也、正面三間詻子、 宝殿如此、大工作料二十石、莫手作料十石、棟上布一端、紙十 帖、苧一両、柱口毎沓形餅四本、饗前又二本、一前宝殿材木、 皆以領家御沙汰也、但板敷足固釗、随入又莫釷、名別千宛弁、 大工饗前、長日同名役也、

(中略)

此御奉行之時造畢、

承久元年〔歳次己卯〕十二月五日〔日次丁卯〕亥時御遷宮畢、 (以下略)

この文書には平面を示した指図(図 1 ) が掲載されている。鎌倉時 代において、神社本殿の指図は珍しい。指図の後には、柱間寸法や 一部の材木寸法が見られる。

先に挙げた「用材注文」と、この「宝殿指図」に挙げられた材木 寸法は同一ではない。柱の長さは、前者が「長九尺六寸三分」、後 者が「長八尺五寸」である。同様に、梁の長さは「長一丈三尺」と 「長一丈一尺」と、いずれも「用材注文」の方がやや長い。したが って、前者は切削等の部材の加工を必要とする用材の注文であるの に対し、後者は仕上がりの寸法を記載した寸法書であると言える。

\section{5. 復元考察}

以上の復元史料を中心として、復元を進めていきたい。なお、「用 材注文」の後半部分が久落しているため、その部分に関しては推定 に留めておく。 


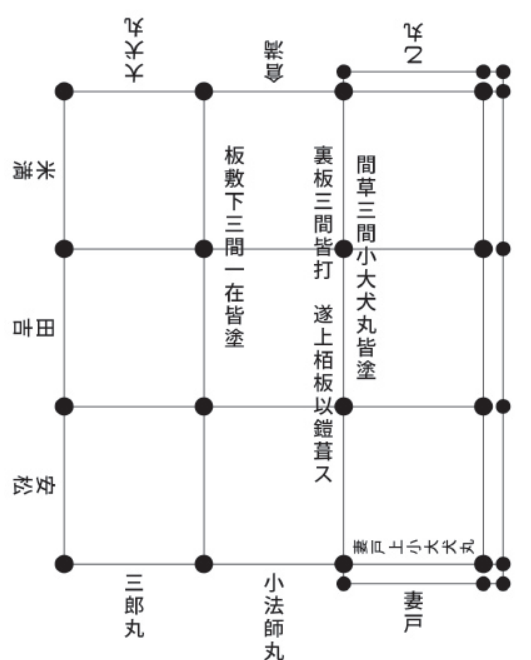

図 1 宝殿指図 (写真本『筑後鷹尾文書』より作成)

\section{（1）構造形式の復元}

\section{【平面】}

平面形式は、「宝殿指図」の平面指図と「御宝殿三間一面広庇」 という記述により、桁行三間・梁間二間を身舎とし、その前面に一 間通りの庇を付し、庇回りにのみ廻縁を設けた平面とすることが確 定される。したがって、指図の向かって右が本殿の正面に相当する。 また、「用材注文」において十六本の柱が計上されていることから、 身舎内部の柱を省略することなく総柱としていたことが分かる。

次に各柱間寸法についてである。まず、「用材注文」に「口間一 面、六尺二寸間」とあることから、桁行は一間を6尺2寸とすること が明らかである。一方、梁間については、「宝殿指図」に「御宝殿 間宛如此、柱長八尺五寸、口七寸五分、梁一天一户、間五户五寸、 正面広庇五尺五寸」（傍点筆者、以下同じ）とあり、梁の長さは1丈1 尺(これは二間分を示している)で、その間すなわち梁間一間分の柱 間は 5 尺 5 寸、正面庇の柱間(庇の出) も 5 尺 5 寸と寸ることが知れる。

以上により、桁行柱間は6尺2寸、梁間は身舎・庇ともに 5 尺 5 寸で あったことが分かる。

\section{【軸部】}

\section{柱}

柱については、「用材注文」に「柱十六本〔長九尺六寸三分、 —九寸 $\square$ 」、「宝殿指図」に「柱長八尺五寸、口七寸五分」 とある。先にも触れたように、柱十六本というのは平面指図に描か れた柱の数と一致し、身舎内部の柱を省略することなく総柱として いたことが分かる。先述のように、「用材注文」は削り代や仕口寸 法等を見込んだもので、「宝殿指図」は建物の各部寸法すなわち部 材の仕上がりの寸法を示したものであることから、柱は長さ8尺5寸 で直径7寸5分の円柱であることが分かる。したがって、削り代及び 仕口寸法等として1尺1枌が見込まれていたことになる。なお、 その長さから掘立柱とするには短すぎるので、礎石建であったこと が想定される。また、「正面広庇五尺五寸、高七尺五寸」とあるこ とにより、庇の高さ注29)（礎石天端から軒桁上端まで）は 7 尺 5 寸とさ れる。なお、「宝殿指図」に「三間一面広庇」「正面広庇」とある ように、前面の一面庇は「広庇」洼30) と記されていることから、庇 柱が角柱であった可能性も否定できない。
梁

梁については、「用材注文」に「梁四枝〔長一丈三尺、五六寸〕」、 「宝殿指図」に「梁一丈一尺」とある。桁行三間であるので身舎梁 は四支必要であり、計上された員数に合致する。身舎梁間は1丈1尺 (5尺5寸間の二間)であり、注文に見える長さ1丈 3 尺は柱や桁との仕 口を考慮して少し長めにとられていることが分かる。

断面に関しては、「用材注文」に「五六寸」（50×6 寸の意）とあ る。用材の仕上げ削りについては、ほぼ同時代の興福寺北円堂を参 照して ${ }^{\text {i331) }}$ 、手斧と槍鉋による削り代を表面と裏面を合わせて 5 分 (1 $5 \mathrm{~mm})$ 程度と推定される。したがって、用材に 5 分の仕上げ削りを施 し、幅 4 寸5 分・成 5 寸 5 分とされる。捨眉や鯖尻を施すには材が細い ので、単なる直材の陸梁であったと考えられる。なお、庇の繋梁に ついての記述は見られない。

\section{桁・棟木}

桁及び棟木については、「用材注文」に「桁三枝〔長二丈六尺六 寸、四五寸〕」、「棟一支、長桁同〔四五寸〕」ある。桁三支は、 身舎前後の桁と庇の桁に一支ずつ、棟一支は棟木として使うものと してよい。なお、螻羽の出については後述したい。桁及び棟木の断 面はともに「四五寸」とあり、5分の仕上げ削りを施して幅3寸5分 ・成4寸5分とされる。

\section{長押}

長押については、「用材注文」に「長押廿四支内〔長二丈十二支、 一丈二尺六支、七尺六支了」と長さの異なる三種の用材が計上され ている。「長二丈」は桁行方向に柱間三間分を通す長押、「一丈二 尺」は梁間方向の身舎二間分を通寸長押、「七尺」は梁間方向の庇 に用いる長押としてよいであろう。

まず、身舎を趈る長押としては腰長押 (外側のみ) と内法長押 (内 外とも)、庇を迴る長押としては縁長押 (外側のみ) と内法長押 (内外 とも)が挙げられる。すなわち、身舎回りに「長二丈」が六支、「一 丈二尺」が六支、庇回り ${ }^{\text {ia } 32)}$ に「長二丈」が三支、「七尺」が六支 必要となる。残る「長二丈」三支は、身舎の棟通りの柱筋で内々陣 と内陣を分ける区画として、腰長押 (外側のみ) と内法長押 (内外と も) に使うとするのが妥当であろう。ここであえて腰長押としたの は、「宝殿指図」の指図内において棟通りの柱筋に添えて「板敷下 三間一在注33) 皆塗」と記されていることから、板敷の下に壁を塗る べき籄所があることが分かり、内々陣は内陣より床高を高めていた と判断されるためである。なお、見方を変えれば、床高の大きな内 々陣の床端部にある見切りの材に当たるので、框とも言える部材で

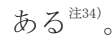

【小屋・軒】

\section{豕扠首}

「用材注文」に「指十二」とあるのは、サス寸なわち豕扠首を示 すものと考えられる。員数が十二とあるのは、扠首束一支と扠首竿 二支の計三支を一組とした四組分の豕双首の用材とすることがで き、四支ある身舎梁上に一組ずつの豕双首を置くものとされる。

\section{垂木}

垂木については、「用材注文」に「垂木井六支内〔長一丈二尺十 二支、広ヒサシ、八尺十二支、一丈三尺十二支、母屋後]」と長さ の異なる三種の用材が計上されている。「長一丈二尺」は「広ヒサ シ」すなわち庇に、「一丈三尺」は「母屋後」すなわち身舎の後流 
れに、残る「八尺」は身舎の前流れに用いる垂木としてよいである う。身舎の垂木は、前流れが短く、後流れが長いので、前流れは身 舎・庇境の桁で止まり、庇の垂木は身舎・庇境の桁から出て庇の桁 を打ち越して掛かるものであることが分かる。

まず、庇の垂木は、身舎柱・庇柱の長さ (8尺5寸・6 尺6 寸) ${ }^{\text {i氵35) }}$ と 柱間 (5尺5寸)より算定すると、3寸5分勾配となる。身舎の垂木の勾 配算定については棟高が必要であるが、いずれの文書においても明 記されていない。そこで、現存遺構を参照したいところであるが、 三間社以上で妻壁のみならず内部の身舎梁上にも豕扠首を配した同 時代の類例はない。同様の架構とするものとしては、文永度の香取 神宮アサメ ${ }^{i 336}$ 殿 ${ }^{677}$ と嘉元造替の上賀茂神社本殿の復元案が挙げら れ、いずれも妻壁と小屋内 (香取神宮アサメ殿は化粧屋根裏) は、同 じ規格の梁と豕双首を用いたことが明らかである。前者は6寸5分勾 配、後者は7 寸5分勾配とする。本稿では両者の平均值を採り、身舎

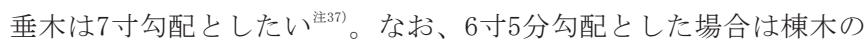
高さは2寸7分5厘低くなり、7寸5分勾配とした場合は2寸7分5厘高く なる程度であり、復元図において視覚的に大きな差異はない。

また、いずれの垂木も十二支が計上されていることから、身舎・ 庇ともに一間を三支割とする大疎垂木 (一枝は約2尺7分)であったこ とが分かる。疎垂木であるので、柱真打として両螻羽には垂木を各 一支ずつ配する計算となり、結局、螻羽の出は垂木二支分となる。 なお、飛檐垂木が「用材注文」にないので、身舎も庇も一軒であっ たことが分かる。

\section{木舞・垂木裏板}

疎垂木上に打たれる木舞については、「用材注文」に「木舞廿四 支」とある。寸法の記載はないが、木舞は桁と同長を渡すものであ り、2丈6尺程の長さを細い一材で渡したとは考えがたく、途中で継 いだ可能性が少なくない。復元図においては、現存遺構を参照し ${ }^{i * 38}$ 、 木舞の間隔は2尺程、一列を二支で継いだものと想定した。

また、「宝殿指図」に「裹板、母屋庇皆打遂也」とあることから、 身舎・庇ともに木舞上に垂木裏板を張っていたことが分かる。

なお、茅負の用材は「用材注文」にないが、弘安八年 (1285)の「瀬 高下庄鎮守大菩薩宝殿修理用途日記」洋39) に、「御宝殿修理用途」

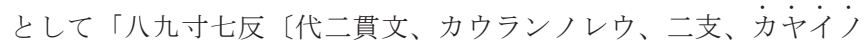
レウ」」と挙げられていることから、承久度本殿にカヤイ住40) 寸な わち茅負はあったしてよいであろう。

\section{軒の出・螻羽の出}

「宝殿指図」に「飛檐三尺五寸、檐雨打四尺二寸、妻差出雨打四 尺五寸」とある。「宝殿指図」の記述は、「飛檐」や「檐」とある ことから軒に関するものであることが分かる。「用材注文」に計上 された垂木で二軒とすることは不可能であるので、「飛檐」とある のは現在でいう飛檐垂木の意味ではないとしてよい。『建築辞彙』 には「飛檐棰」は「二軒ノ場合二、最も外方ナル棰ニシテ、茅負 承クルモノナリ。(中略) 又一軒ニテモ、反アラバ飛檐棰ナリ。（以 下略)」の後者に当たるものと考えられる。すなわち、反りのある 垂木を意味していると考えられ、「飛檐三尺五寸」は反りのある垂 木が 3 尺 5 寸と解釈される。垂木の項で述べたように、垂木はそれよ りもずっと長い材であるので、垂木の単純な長さではなく、垂木の 出すなわち軒の出を示している可能性が少なくない。

また、それに続き、「檐雨打」、「妻差出雨打」というように「雨
打」という単語が見える。もちろんこれは対のものを示していると 考えてよいであろう。「妻差出雨打」は、妻に差し出す雨打(軒)す なわち螻羽が想定される。軒の出が 3 尺 5 寸で、「檐雨打」が 4 尺 2 寸 である。軒の出は側柱真から垂木先端までであり、「檐雨打」はそ れよりも7寸長いので、板莫屋根 (詳しくは後述)の先端までとする のが穏当であろう。したがって、対に記されていた「妻差出雨打」 についても、側柱真から螻羽の板莫屋根の先端までを示していると 考えられる。

以上により、軒の出は側柱真から 3 尺 5 寸、板莫屋根の先までが側 柱真から 4 尺 2 寸と推定され、螻羽の屋根先までが側柱真から 4 尺 5 寸 と考えられる。

【破風・屋根莫】

\section{破風板}

破風板については、「用材注文」に「博風六枚」とあることから、 垂木と同様に身舎の前流れと後流れ、庇の流れとで別木としていた ことが分かる。

破風板を身舎と庇で別木とするのは、嘉元造替の上賀茂神社本殿 や仁治度㛜島神社社殿洋41)で行われていることがすでに明らかであ り、当時代の傾向と言える。

\section{開板}

「用材注文」に「開板二枚、長同桁」とある。この開板は、長さ が桁と同じというから、桁行方向に用いる材木であると考えられる。 開板という材は、仁治度厳島神社社殿の用材注文である暦仁二年 (1 239）の「伊都岐島社未造分屋材木等注進状」洋42) においても、今社 拝殿・朝座侍屋・筐殿平門に「破風開板」あるいは「開板」として 挙げられている。この三棟はいずれも板莫である注 33 ことから、板 莫とする際に必要な材で桁行方向に用いるものであることが分か る。本復元案においては、ひとまず屋根頂部の覆い(障泥板) と想定 しておく。

\section{屋根莫}

屋根莫に関しては、「宝殿指図」の「裹板三間皆打遂上柏板以鎧 莫ス」と「母屋二間平殿上柏板長三尺、面四五六寸、若檐板七八寸、 凡五千余枚、直米八石余下取、鎧草〔スル〕也」という記述がある。

まず、先の記述により、垂木上にはすべて裏板を打ち、その上に 栢板を蕞くことが分かる。次に、その柏板は母屋二間(梁間)の平殿 上において長さ3尺、幅4寸や5 寸や6 寸であり、また、檐板は幅7寸 や8寸であり、それらは五千余枚あるという。ここから二種類の莫 板があることが知られ、身舎には幅の狭いもの、残る庇には幅のや や広いものを用いるようである。これらを桁行方向に一列に並べる と、一列につき前者は約 56 枚、後者は約 37 枚必要となる。仮に莫き 足を1尺とすると身舎の前流れに三列、後流れに六列、庇に五列が 必要となる。栢板は五千余枚とあるので、一列に七枚から八枚重祆 て莫くものと算定される。莫板を重社て莫くのであるから、この屋 根は長柿亘の一種である段柿莫 ${ }^{(i 44)}$ と言えよう。また、この莫板を 留めるための母屋桁が野屋根内にあったものと想定される。

なお、以上のように重ねた柏板や檐板をずらしながら莫くことに より、小札を重㸚た鎧のように見えたことから、鎧莫と称された可 能性がある。

【床】

「用材注文」にある「大床下梁四支〔五六寸、長一丈三尺〕」は、 
大床の下にある梁すなわち大引と考えられる。中世において大床は 廻縁を示寸ことが少なくないが、「用材注文」の中では、廻縁は「縁」 (「縁角木」とあることによる) と記されている。したがって、当文 書において大床は迴縁を示すものではないとしてよい。また、1丈1 尺の身舎梁間に対して1丈 3 尺の「大床下梁」は、身舎下の大引の用 材として適当な長さである。

断面は、「五六寸」に仕上げ削りを施し、幅 4 寸5分・成 5 寸5 分と される。なお、「用材注文」に根太に相当寸る用材は計上されてい ないが、床板を張るために必要となるため復元図に補加した。

床板については、「用材注文」に「板敷板」等の記述は見られな い。但し、後半の久落部分に、「口百六十枚〔但後継定〕、 「口六十四枚〔長六尺五寸〕、「口枚〔長一丈二尺、 広一尺]」という板材が計上されており、これらのうちいずれかが、 床板を示すものである可能性がある。

\section{【組物】}

組物の用材として「用材注文」に「斗二」と「臂木十六」が挙げ られている。このうち二つの斗は、両妻において身舎梁の中央下を 受ける大斗とするほかはない。そして、肘木(「臂木」) は、組み合 わせる斗がないので舟肘木であることが分かる。

まず、舟肘木が必要となるのは、棟通りを除く注45) 身舎柱上と庇 柱上の十二箇所である。それぞれ一支ずつ用いて十二支を使う。次 に、豕双首上に棟木を受ける舟肘木が必要であり、四組の豕双首上 に一支ずつ配して四支を使う。合わせて十六支となり、計上された 員数に合致する ${ }^{(i 46)}$ 。

【建具・壁】

\section{建具}

まず、「宝殿指図」に「正面三間詻子」とあることから、正面三 間は格子寸なわち部としていたことが分かる。また、平面指図にお いて、庇の向かって左側面の柱間に「妻戸」とあり、板扉が設けら れていたことが知れる。但し、いずれも「用材注文」に見られない。

また、平面指図における内外陣境の柱筋には「間草三間小大犬丸 皆塗」と記されている。詳しくは次項で述べるが、「小大犬丸皆塗」 は小大犬丸 (名)が板壁に漆喰を塗る負担をすることを意味すること から、この三間の間草上(小壁のこと) が板壁であったことは分かる。 建具に関しては、「宝殿指図」に「詻子」や「妻戸」の記載がある ことから、記載のない柱間には建具はなかったとしてよいであろう。 したがって、内外陣境の各柱間は、内法長押下は間草を渡すのみで 開放されていたと考えられる。なお、内々陣正面の柱筋においても 同様に建具はなかった可能性が高い。

\section{壁}

「宝殿指図」に描かれた平面指図の側回りにおいて、建具（蔀及 び妻戸) 以外の柱間には「小法師丸」や「三郎丸」といった「名」注77 (造営負担者)が記載されている。平面指図の脇に「如此名〉一間宛 塗蠣灰名別二斗宛入」とあることから、名の記された箇所は板壁を 蠣灰塗としていたことが分かる。

また、妻戸の柱間には「妻戸上小大犬丸」、内外陣境には「間草 三間小大犬丸皆塗」とあり、妻戸上及び内外陣境の間草上において、 先の板壁と同様に蠇灰塗を施す小壁があったとしてよい。加えて、 長押の項において述べたように、内々陣正面には「板敷下三間一在 皆塗」とあることから、腰長押 (框)下にも同様の板壁が嵌っていた
ものと考えられる。

【廻縁・木階】

廻縁

廻縁の用材として「用材注文」に「縁柱十本〔長三尺、口六寸〕」 と「縁角木二支〔長七尺、五六寸〕」が挙げられている。平面の項 にて述べたように、「宝殿指図」の平面指図により、庇回りにのみ 縁があったことは明らかである。その平面指図の廻縁には、庇の側 柱筋に対応する位置と正面両隅の計十箇所に黒点が描かれており、 それが「縁柱」すなわち縁束を示すものと考えられる。したがって、 用材として計上された縁束十本と縁角木二支は、必要な員数に合致 する。

縁束は「口六寸」とあることから円柱であることが分かり、仕上 げ削りを施し直径 5 寸 5 分とされる。縁束の長さすなわち縁の高さに ついては、次項にて詳述する木階との関係で、木階四級分 (一級の 成が4寸5分) の1尺8寸と算定される。また、縁の出については、縁 角木の用材が「長七尺」であることから、側柱真から 4 尺注48) の出と するのが適当であろう。

なお、縁板の用材は「用材注文」に見えない。後半の欠落箇所に 挙げられている可能性も否定できないが、詳細は不明である。復元 図においては、類例の多い切目縁とした。加えて、高欄の用材も「用 材注文」にないが、「瀬高下庄鎮守大菩薩宝殿修理用途日記」に、 「御宝殿修理用途」として「八九寸七反〔代二貫文、カウウシう ウ、二支、カヤイノレウ]」と挙げられていることから、承久度本 殿の廻縁には高欄があったと考えられる。

木階

「用材注文」の「勊橋木四支〔長九尺、同下桁〕」は、キザハシ キすなわち木階のための材木としてよい:注49)。「宝殿指図」の平面指 図に木階は描かれていないが、通例に従い正面中央に配していたも のと考えられる。長さに続けて「同下桁」とあるが、同文書に倣う べき「下桁」は見られない。そこで本稿においては、「大床下梁」 の「五六寸」を採用し、幅 5 寸 5 分・成 4 寸 5 分の木階四級を復元図に 付した。

\section{（2）承久度本殿の構造形式}

以上の考察結果に基づき、復元された承久度本殿の形式を改めて 述べておきたい(図 $2 \sim 7$ )。

桁行三間 (柱間 6 尺 2 寸) ・梁間二間 (柱間 5 尺 5 寸) を身舎とし、その 正面に一間 (柱間 5 尺 5 寸) 通りの庇を付けた三間社流造、段柿莫とす る。庇回りにのみ縁を廻らせ刎高欄を設け、正面中央には四級の木 階を置く。

身舎を内陣、庇を外陣とする。身舎の棟通りの柱筋より奥は内々 陣とする。内陣の両側面及び背面は蠣灰塗の板壁を嵌める。外陣正 面は蔀を吊り、向かって左側面は妻戸を建て、右側面は蠣灰塗の板 壁とする。

亀腹上に礎石建とし、総柱とする。梁間方向の柱間に渡した大引 上に根太を配し、床板を張る。縁長押・腰長押と内法長押で柱を固 める。内外陣境において内陣側の床板を長押一本分高め、さらに内 々陣は内陣よりも床を高くし神座とする。

身舎柱には梁を架け、豕扠首を載せる。豕扠首上には舟肘木を配 し、化粧棟木を受ける。組物は身舎・庇ともに舟肘木とし、身舎の 妻面中央柱上のみ大斗と寸る。身舎・庇ともに一軒疎垂木とし、化 
粧垂木上には茅負及び木舞を載せ、垂木裏板を張る。野屋根は、段 柿莫のための母屋析が載る程度でほとんどない。屋根の頂部には開 板を置く。

\section{6. 承久度本殿の特色とその背景}

\section{（1）承久度本殿の建築的特色}

復元された承久度本殿における特徽的な形式として、庇回りにの み縁を迴らせること、床高が低いこと、段柿莫の屋根とすること、 身舎・庇ともに大疎垂木の一軒とすることが挙げられる。

まず、廻縁についてであるが、流造本殿は身舎も含めた四面もし くは三面 ${ }^{i 50)}$ に廻縁を廻らせることが多いが、承久度本殿において は庇回りのみにしか設けていない。庇の向かって左側面の柱間にの み開かれた妻戸は、明らかに出入りのためのものであることから、 実用する箇所に限って縁を廻らせたものと考えられる。すなわち、 庇回りのみの縁は、通常の廻縁を省略した形式と言えるであろう。 また、全体的に床高が低いことについても、本殿として必要最低限 の形式を採ったものと考えられ、それを解消寸るために内部におい て内々陣の床高を内陣より高めた可能性がある。

次に、屋根莫についてである。前述のように、建暦二年に修理の ための檜皮が注文されており、建暦三年焼失以前は檜皮莫であった 注51) ことが明らかである。したがって、承久度において檜皮草から 段柿莫へと格式を下げて再建されたことが分かる。

そして、最も注目されるのが垂木割である。一般的に三間社流造 本殿は、その原型とされる上下賀茂神社の本殿のように、身舎の垂 木は繁垂木とし、庇の垂木は大疎垂木とするか、その発展形式であ る身舎・庇ともに繁垂木とするかのいずれかである。しかし、承久 度本殿はそのいずれでもなく、身舎・庇ともに大疎垂木という異例 の形式をとる。先に挙げた迴縁の形式や屋根莫等を勘案すると、通 常の垂木割を省略したものとするのが穏当であろう。

なお、永井氏はこの垂木割について「流造の古い形式を示すもの かも知れない」とし、また、繁垂木と疎垂木の区別が空間の意味に 対応する性格を持つならば、「身舎と庇において構造的な区分はあ るものの、空間の性格は等質であり、ともに神の場となっていたと 考えられるのである」としている。さらに、「立面構成の低平さは、 神社建築としての古様性に基くのかも知れないが、もともと前室と しての庇への人の入室を前提としなかったことによるとも考えられ る」と述べている。しかし、屋根莫の変更等から明らかなように、 承久度本殿は前身本殿をそのまま再現したものではないことから古 式を伝えているとは言い難い。また、庇の妻戸と迴縁の配置から、 少なくとも外陣である庇には神官が入るように設計されていたと考 えた方がよいであろう。

\section{（2）仮屋の可能性}

承久度本殿が省略された形式及び格式を下げた形式を呈すること になった背景について考察したい。そこで、承久元年遷宮後の様子 を示した仁治三年の「高良別宮神官等申状」を改めて引用すると、

昔宝殿及大破、礎石徒変苔下、悲哉、今仮屋忽令朽損营不全、

爱適去天福年中、僅構板庇白地奉移許也、其後就代>預所、雖 令言上子細、連 $\square$ 得替之故、于今未達前途、自然送年重月之間、 仮屋已 $\square$ 落雨露更不止、御正体又及露頭哉、顛倒在近者歟、

とある。この「昔宝殿及大破」とは建暦三年の社殿焼失を示してい
ると考えられ、「今仮屋忽令朽損蒙不全」とあることから、今 (仁 治三年当時) は仮屋が朽損し、甍 ${ }^{* 52}$ (屋根) は不全であると解釈され る。したがって、承久度に「御宝殿」として再建されたのは、この 仮屋であったと考えられる。

他社の例を見ても、中世において経済的に困難となり古来より伝 わる社殿の形式を維持できなくなった神社が少なくないが、その中 でも当社の事例に近いものとして、本殿を仮殿で代用した出雲大社 と香取神宮が挙げられる。

出雲大社の場合、宝治二年 (1248) に遷宮された正殿が文永八年 $(1$ 271)に焼失した。その再建に際しては、まず仮殿を造営しようとし たが未完の状態が長く続き、元亨三年 (1323) もしくは正中二年 $(132$ 5)にようやく仮殿が完成し遷宮が行われ、その後も仮殿が恒常的に 正殿の代用となったと考えられている ${ }^{8)}$ 。また、香取神宮の場合、 元徳二年 (1330) に遷宮された正神殿が永享五年 (1433)までに失わ れ、その後は仮殿であるアサメ殿が正神殿の代用とされたという。

以上の二例は、いずれも本殿の造営が困難となった際に将来本殿 を改めて造営することを前提として、さしあたり仮殿を建てて本殿 の代用としたものと言える。その仮殿が本殿より略式であった ことは言うまでもない。当社においては、再建の際に「御宝殿」の 用材を注文し遷宮を行ったと明記されていることから、往時は本殿 として認知されていたとしてよい。但し、部分的に形式を省略し、 格式を下げて再建を遂げた結果、後世に仮屋と呼ばれる形式となっ てしまったと推測される。

\section{( 3 ) 高良大社の影響}

また、総柱とすること、庇の垂木を身舎・庇境の桁に掛けること についても承久度本殿の特徵的な形式として挙げられる。これらの 形式は、先述したような省略された形式あるいは格式を下げた形式 とは言えず、別の要因によるものと考えられる。

まず、総柱とすることについては、当社の本社に相当する高良大 社本殿注54) の古式と一致する形式である。中世における高良大社本 殿については佐藤正彦氏 ${ }^{9}$ 、三浦正幸氏 ${ }^{10)}$ 、米澤貴紀氏等 ${ }^{11}$ の諸説 があるが、いずれにおいても総柱の本殿が復元されている ${ }^{i 555}$ 。ま た、三浦氏は『高良玉垂宮神秘書』溇56)に記された内々陣(「内殿」) の壁や扉に描かれた絵の配置についても検証し、内々陣の中央三間 は相互の間に仕切りがなく一室としていたことを明らかにしており i注57)、この点についても承久度本殿と共通寸る ${ }^{i(58)}$ 。

次に、庇の垂木についてである。元来、流造本殿の庇は二系統あ り、上下賀茂神社の本殿のように角柱とし建具等を設けない庇と、 伏見稲荷神社本殿のように円柱とし建具等で囲われた庇である。前 者の場合、庇の垂木は身舎正面軒の茅負 (もしくは木負)から打越垂 木として掛けるのに対し、後者の場合、身舎・庇境の桁上に掛ける。 承久度本殿はその後者に相当するものであり、中世の高良大社本殿 の庇についても同様である。

加えて、承久度本殿の庇において、正面に蔀、側面に妻戸を建て ることは、宗像大社辺津宮本殿や笘崎宮本殿等の社格が高い大きな 本殿に見られる形式であり、中世の高良大社本殿もこの形式を採っ ていたと考えられている洋59

したがって、承久度本殿は中世の高良大社本殿と共通する特徵が 少なくなく、当社本殿がその影響を受けて成立した可能性が十分に あると言えるであろう。 


\section{7. 結語}

復元考察の結果、先学による復元案とはやや異なるものとなった。 承久度本殿に見られる特徵のうち、庇回りにのみ縁を廻らせること、 床高が低いこと、段柿莫の屋根とすること、身舎・庇ともに大疎垂 木とすることは、通常の本殿を省略した形式あるいは格式を下げた 形式と言える。これは、経済的事由により焼失前の前身本殿の形式 を維持できなくなったための、やむをえない措置と考えられる。ま た、総柱とすること、庇の垂木を身舎・庇境の桁に掛けること等、 中世高良大社本殿と共通する特徴が少なからず見られ、その影響を 受けて成立したものとしてよい。

承久度本殿は、用材注文に加えて宝殿指図も伝えられているため、
より確からしい復元が可能であった。したがって、類例の乏しい鎌 倉時代前期の流造本殿の一形式を示寸貴重な例と言える。また、高 良大社の影響下で成立し、上下賀茂神社とは別系統の流造本殿であ ることから、流造本殿の発展過程を考察する上でも重要な位置を占 めるものと言えよう。その一方で、一般的には中世後期に多く見ら れる本殿の縮小が、当社においては承久元年という比較的早い時期 に行われたことも注目に值する。

なお、本稿は科学研究費補助金 (特別研究員奨励費)「古文書によ る社寺建築等の復元と中世の建築工事に関寸る研究」の成果の一部 である。

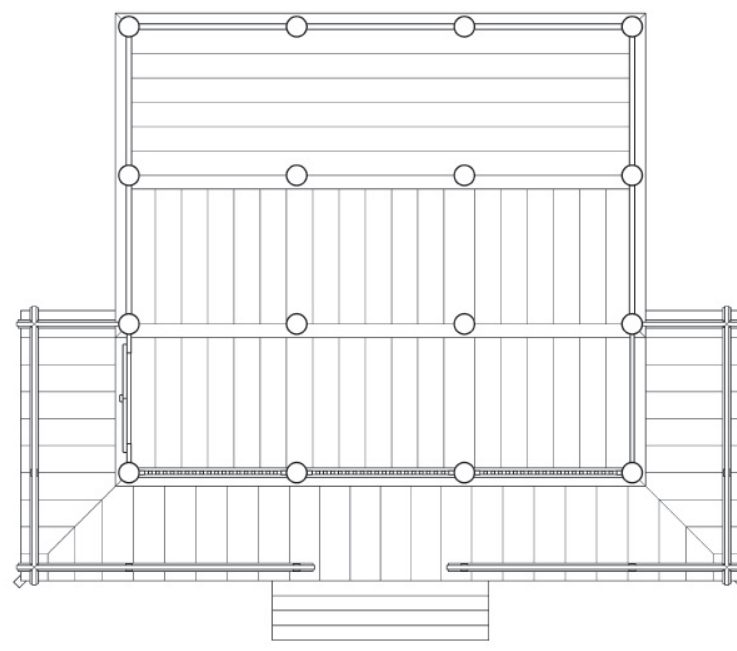

40

62 62

図 2 復元平面図
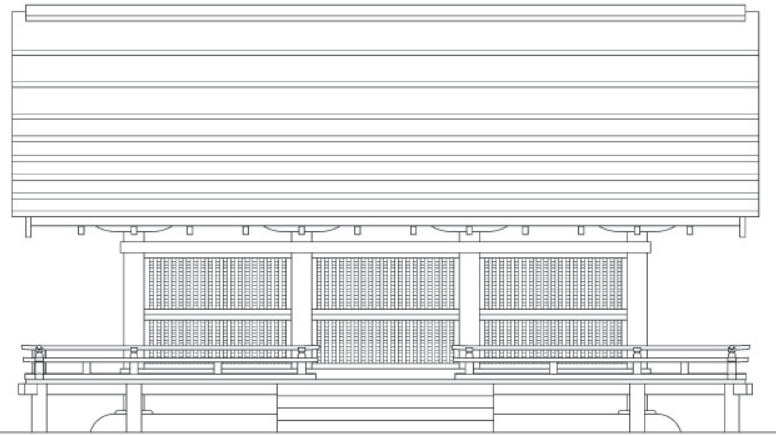

図 4 復元正面立面図

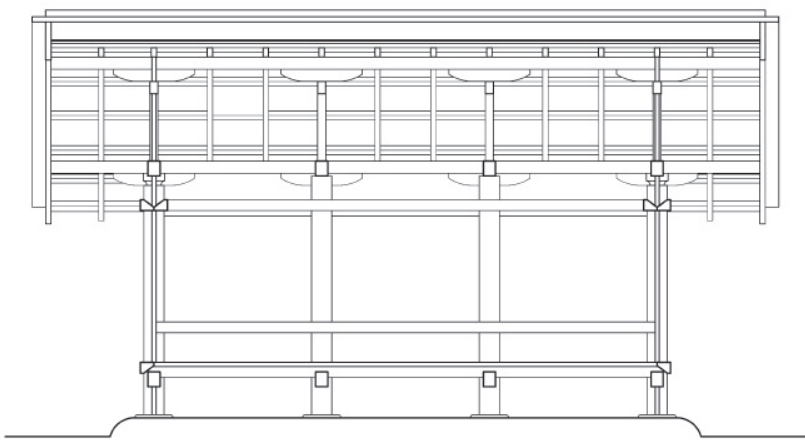

図 6 復元桁行断面図

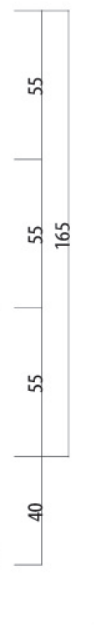

単位：寸

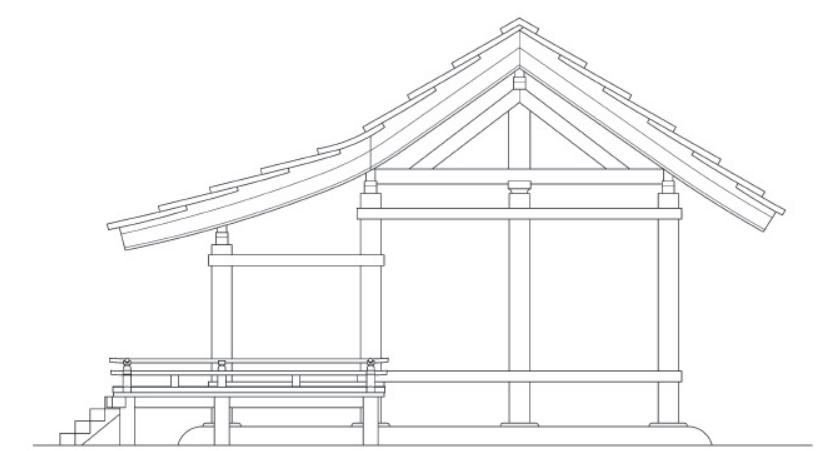

図 5 復元側面立面図

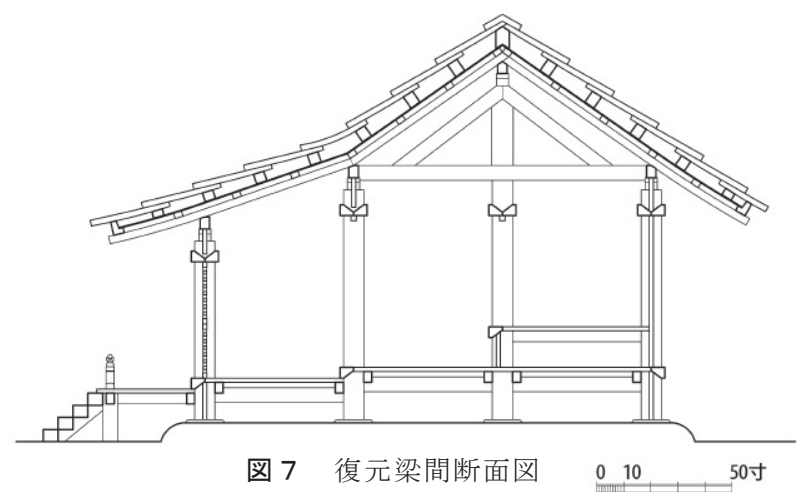




\section{参考文献}

1) 佐藤正彦：鷹尾神社本殿について一承久元年再建時の指図より一, 日本建 築学会大会学術講演梗概集, pp. $1847 \sim 1848,1977.10$

2) 永井規男: 鷹尾神社承久再建本殿の建築構成について, 技苑, 第 48 号, pp. $46 \sim 50,1986.8$

3) 谷重雄：上賀茂神社嘉元造替の本殿, 建築史, 二八四, pp. 295 316, 194 0. 7

4) 熊本中世史研究会編 : 筑後鷹尾文書, 青潮社, 1974

5) 柳川古文書館編 : 筑後鷹尾文書, 福岡県地方史研究連絡協議会, 1995

6) 福山敏男: 香取神宮の本殿, 日本建築史研究, 墨水書房, 1968

7) 三浦正幸：香取神宮本殿，日本建築学会計画系論文報告集，第362号，pp. 142 149, 1986. 4

8) 三浦正幸：出雲大社本殿。太田博太郎編：日本建築史基礎資料集成一(社 殿 I )，中央公論美術出版， 1998

9) 佐藤正彦：中世期に於ける高良神社本殿について, 日本建築学会大会学術 講演梗概集，pp. 2645～2646，1983.9

10) 三浦正幸：高良大社本殿，四面庇系平面の神社本殿の研究，私家版 (東京 大学博士論文), 1986

11) 米澤貴紀 - 永井規男 - 中川武 - 溝口明則 - 河津優司 ・坂本忠規 ・佐々木 昌孝・小岩正樹・伏見唯 :『木砕之注文』を通してみた室町中期高良大社本 殿平面形式の復原, 2009年度日本建築学会関東支部研究報告集, pp. 509 5 12, 2010. 3

\section{注}

注1) 活字本『筑後鷹尾文書』(参考文献4)による。

注2) 鷹尾家文書 (遷宮祭礼関係文書写の部)一。この文書は、保元四年 (1159) と承安三年 (1173)の記のある二通よりなる。以下、す心゙ての文書番号は、 活字本『筑後鷹尾文書』(参考文献4) による。

注3) 鷹尾家文書 (遷宮祭礼関係文書写の部) 四。この文書は、正治元年 (1199) から建暦三年 (1213) までの七通よりなる。

注4) 鷹尾家文書 (遷宮祭礼関係文書写の部)七。この文書には別文書が錯簡し て入り、それが書写され連続した一文書となっている。引用部分はその錯 簡部分に相当する。

注5) 建暦二年 (1212)「遷宮諸役次第科別宮仏前御供支配注文」（鷹尾家文書 〈遷宮祭礼関係文書写の部〉六)に「建暦二年〔歳次壬申〕宮移十一月日」 とあることによる。

注6)鷹尾家文書 (遷宮祭礼関係文書写の部)一○。なお、同文書に「但御正体 八惣検校華王房取出参幡御鉾同」とあることにより、御正体 (神体) は内陣 装束の幡や鉾とともに取り出して無事であったことが分かる。

注7）「瀬高下庄領家下文」(鷹尾神社文書二)においても社殿焼失の記述が見 られる。

注8）「御宝殿造営用材注文」(鷹尾家文書〈遷宮祭礼関係文書写の部〉一二) による。

注9）「鷹尾社遷宮宝殿指図科用途直法等注文」（鷹尾家文書〈遷宮祭礼関係 文書写の部〉一四)による。

注10)鷹尾家文書 (一紙文書の部) 一三

注11）「高良別宮大宮司紀元保申状」(鷹尾家文書〈一紙文書の部〉一六)に 「当社守護御宝殿造営事、去仁治三年 $\square \square \square$ 一名〔限二ヶ年所当〕可造畢 之由、被仰下之処、以件名二ヶ年分 $\square \square$ 十余石難造畢之上、即名頭百姓等 未済雖有其 $\square \square \square$ 廻随分秘計、加屓負御造営雖修其功」とあることによる。 また、「鷹尾社神官等言上状案 (前欠)」(鷹尾家文書〈一紙文書の部〉一七) からも知られる。

注12) 鷹尾家文書 (一紙文書の部)一七

注13）「鷹尾社宝殿上莫用途日記」(鷹尾家文書〈一紙文書の部〉一八)によ る。

注14）「鷹尾社遷宮用途例言上状案」（鷹尾家文書〈一紙文書の部〉一九）に よる。

注15）「瀬高下庄鎮守大菩薩宝殿修理用途日記」（近世写本鷹尾文書四）によ る。

注16）「高良別宮遷宮用途注進状案」（鷹尾家文書〈一紙文書の部〉二八）に よる。

注17) 鷹尾家文書 (一紙文書の部) 七六
注18)「鷹尾社造営願案(後欠)」（注17参照)に「立斎様御代神殿破壊に付而 奉願候処二、 $\square$ 神殿不及申、楼門無残所御建立被遊候」とあることによる。 注19)「鷹尾社造営願案 (後欠)」(注17参照)による。

注20）『柳川の社寺建築 II』（柳川市史編集委員会編，柳川市，2011）を参照 されたい。

注21) 注8参照。

注22)注9参照。

注23) 佐藤は、現存する神社本殿 (国指定重要文化財) のうち瓦葺とする四棟 (日部神社本殿 - 鶴林寺行者堂・㛜島神社末社豊国神社本殿・大神神社摂 社大直禰子神社社殿) を挙げ、承久度本殿が瓦莫であった傍証としている。 しかし、それを類例とするには以下のような難点がある。

まず、日部神社本殿は、桁行三間・梁間三間(背面は二間)の正面に三 間の向拝を付す。細部意匠等により、本体は十六世紀後期から十七世紀頃、 向拝は十四世紀後期頃の建築と考えられ、もとは本体と向拝が別の建物で あったものと推察される。本体は神社本殿というよりはむしろ仏堂の平面 に近く、屋根も入母屋造妻入であることを勘案すると、神社の本地堂 (も しくは薬師堂) 等の仏教建築であった可能性が指摘できる。すなわち、日 部神社本殿は純粋な神社本殿であったとは認められない。また、鶴林寺行 者堂は、寺院内の鎮守堂である。そして、厳島神社末社豊国神社本殿は、 もとは大経堂として建てられ、神仏分離により神社本殿とされたものであ り、大神神社摂社大直禰子神社社殿も、もとは大御輪寺本堂として建てら れ、明治初年に若宮社の社殿に転用されたものである。以上のように、佐 藤が挙げた四棟の神社本殿は、いずれも承久度本殿が瓦莫であったことの 傍証にはならない。

注24) 活字本 (参考文献4)では「尺」とされている。 注25) 活字本 (参考文献4)では「口」とされている。 注26)活字本 (参考文献4)では「口」とされている。 注27)活字本 (参考文献4)では「十」とされている。 注28) 前述のように、活字本 (参考文献4)では「瓦」とされている。 注29)身舎柱については「柱長」とあるのに対して、庇については「高七尺 五寸」とあえて「高」と記されていることにより、庇柱の長さではなく、 庇の高さを示していると考えられる。

注30) 寝殿造の広庇(「年中行事絵巻」の法住寺殿や東三条殿を描いた場面等 に散見される)であれば、外側の柱は面取角柱で柱間は吹放ちとし、床は身 舎よりも長押一本分低くするのが通例である。

注31) 興福寺北円堂は、承元四年 (1210) に建立されたものである。『重要文化 財興福寺大湯屋 - 国宝同北円堂修理工事報告書』(奈良県文化財保存事務所, 1965)によれば、材木の表面仕上げとして手斧及び槍鉋で $5 \mathrm{~mm}$ から $8 \mathrm{~mm}$ 削られ ているという。

注32)身舎・庇境は、身舎側に長押を廻らせるので、庇としては三面に長押 を廻らせることとなる。

注33)ここにいう「一在」は、造営料を負担した「名」である。「名」に関し ては、すでに佐藤の論考(参考文献1)により明らかである。

注34) 太さについての記述はないが、同時代の現存遺構 (西明寺本堂や法隆寺 東院礼堂等) を参考として、柱に対する比率により、長押の成は4寸とし、 ほぼ台形断面を呈していたと想定される。

注35)身舎柱・庇柱上は、いずれも舟肘木 (寸法の記述がないので成は推定と なる) と桁 (成4寸5分)を載せるという同様の形式と考えられるので、それら を含めなくても垂木勾配に影響はない。

注36)アサメの漢字は「女」偏に「盛」。

注37) 垂木の太さについての記述はないが、同時代の現存遺構 (注34参照) 参考として、柱に対する比率により、垂木の成を2 28 分、幅を2 寸と算定さ れる。

注38) 当麻寺本堂の閍伽棚は疎垂木木舞裏であり、その木舞間隔は約 2 尺 2 寸 である。

注39)近世写本鷹尾文書四

注40) カヤイは茅居と書き、茅負を指す語である。

注41）拙稿「仁治度㛜島神社楽屋の復元的研究」（建築史学，第51号, pp. 68 〜 93，2008. 9）及び拙稿「仁治度厳島神社朝座屋の復元考察」（芸備地方 史研究，第 $275 \cdot 276$ 号，pp. 1〜22，2011．4）を参照されたい。

注42）『広島県史古代中世資料編III』（広島県，1978）に所収。

注43) その他の檜皮莫の社殿に開板の用材は見られない。 
注44) 同様に細長い柿板を用いて屋根を莫く例としては、常磐神社玉殿第一 殿（広島県安芸高田市八千代町所在、天文年間〈1532 1555〉建立）が挙 げられる。常磐神社に使われた柿板は、長さ1尺及び1尺7寸、幅 2 寸 8 分から 5 寸4分、厚 1 分 8 厘であり、莫き足は9 寸という。詳しくは、山田岳晴・三浦 正幸「安芸国の中世神社玉殿における屋根構造の調査研究」（日本建築学会 計画系論文集，第572号，pp. 139〜145，2003，10）を参照されたい。

注45) 身舎柱のうち、棟通りにおいては舟肘木を配す必要がない。妻壁にお いては大斗を配し、内部の柱 (内々陣・内陣境の柱) は身舎梁下となるため、 舟肘木は不必要である。

注46)大斗及び舟肘木は員数のみの記載であるので、寸法については同時代 の現存遺構 (神谷神社本殿、金剛峯寺不動堂、高山寺石水院等)を参考とし、 復元図に付した。

注47) 注34参照。

注48）「用材注文」に計上された用材と仕上がり寸法を比較すると、1尺（継 手・仕口は含めず)以上は余分に見積もってあることが分かる。縁角木につ いても同様とすると、側柱から縁隅木端部の長さは6尺以下に収まるものと 想定され、そのためには縁の出が側柱真から4尺とするのが適当である。 注49)佐藤は、この記述により「正面中央間の縁の前に長さ9尺の階段五段が 設けられていたらしい」とする。しかし、用材が9尺なのであって、実際は それより少し幅の狭いものとなる。また、段数は四段の誤りであろう。

注50)特に三間社流造本殿の現存遺構において、身舎も含めた三面に廻縁を 設けることが圧倒的に多い。承久度本殿と同様に庇回りのみの廻縁とする 三間社以上の中世の流造本殿は、永井氏の指摘にもある龍山八幡神社本殿 (広島県) と雄山神社前立社壇本殿 (富山県)のみである。

注51)「鷹尾社祭礼神官装束等覚科御財物日記」(注4参照)の記述による。

注52) 甍は瓦のみならず屋根を示すこともある。ほぼ同時代の建暦二年 (1212)

頃の成立とされている『方丈記』に、「玉敷の都のうちに、棟を並心゙甍を争
へる、高き賤しき人の住ひは、世々を経て尽きせぬものなれど、これをま ことかと尋ぬれば、昔ありし家は稀なり」という一節があるが、ここにい う营は、住居の屋根を意味している。往時の住居の屋根は草莫や板莫や檜 皮莫等であることから、曹は瓦莫の意ではなく、広く屋根の意に用いられ ていることが分かる。

注53) 出雲大社は正式な仮殿ではなく摂社 (阿式社) の寸法をとるものとし(参 考文献8)、香取神宮は正神殿五間に対して仮殿三間であった(参考文献 $6 \cdot 7$ ) ことから、本殿よりも仮殿が略式であったことは明らかである。

注54) 現在の高良大社本殿は、寛文元年 (1661) の再建になるもので、桁行三 間・梁間一間の内陣の前面に二間通りの外陣を備えた桁行三間・梁間三間 の平面とする。したがって、それ以前の形式を保っていない。

注55) 中世の高良大社本殿に関しては、佐藤、三浦、米澤等により、それぞ れ復元が行われている。佐藤と三浦はともに、『高良玉垂宮神秘書』の記述 により、桁行五間・梁間五間で総柱に復元している。米澤等は、『木砕之注 文』の記述により、桁行五間・梁間四間で総柱に復元している。なお、本 殿の年代については、佐藤は中世、三浦は天文十四年、米澤等は室町時代 中期としている。

注56)『高良玉垂宮神秘書同紙背』(高良大社，1972）に所収。

注57)内殿の絵について考察したのは三浦のみである。また、米澤等によれ ば、『木砕之注文』には内殿の仕切壁について記述はないという。

注58)年紀未詳であるが「障子張替注文」(鷹尾家文書〈遷宮祭礼関係文書書 写の部〉二○）に「御障子キ帳ノカヘシロノ帳」とあることから、当社本 殿の内々陣には、衝立の障子が立てられていた可能性がある。 注59)三浦の復元案による。

（2012年 4 月 10 日原稿受理，2012年 6 月 4 日採用決定） 